\title{
Prevalence, severity and factors associated with peripheral neuropathy among newly diagnosed diabetic patients attending Mulago hospital: a cross-sectional study.
}

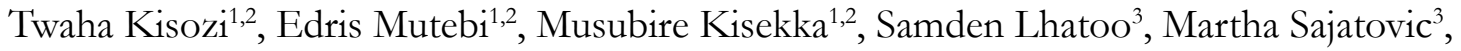 \\ Mark Kaddumukasa ${ }^{1,2}$, Fredrick Nelson Nakwagala ${ }^{1,2}$, Elly Katabira ${ }^{1,2}$
}

1. Department of Medicine, Mulago Hospital, P.O. Box 5052 Kampala, Uganda

2. Department of Medicine, School of Medicine, Makerere University, College of Health Sciences, P.O. Box 7072 Kampala, Uganda.

3. Neurology Institute, University Hospitals Case Medical Center, 11100 Euclid Avenue, Cleveland, OH 44106, USA

\begin{abstract}
Aims: To determine the prevalence and associated risk factors of diabetic peripheral neuropathy (DPN) among newly diagnosed diabetes mellitus patients in Mulago Hospital.

Methods: A cross-sectional study was conducted among 248 newly diagnosed adult diabetic patients. Using the standard Neuropathy Symptom Score (NSS) and Neuropathy Disability Score (NDS) criteria, we screened them for neuropathy. Data on the socio-demographics, age, duration of symptoms and history of diabetic ulcer were analyzed using a multiple logistic regression. A p-value $<0.05$ was considered significant.

Results: The majority of study patients $(62.1 \%)$ were male. The overall prevalence of DPN was $29.4 \%$. Nearly sixteen percent had moderate neuropathy and only five percent had severe neuropathy. Age above 60 years was significantly associated with the presence of DPN; (OR 3.72; 95\% CI 1.25 - 11.03; $\mathrm{p}=0.018)$. The history of ever having a foot ulcer was significantly associated with peripheral neuropathy (OR 2.59; 95\% CI: $1.03-6.49, \mathrm{p}=0.042$ ).

Conclusion: DPN occurs in 1 in 4 of newly diagnosed diabetic patients in Mulago hospital. Two thirds of these patients had moderate to severe neuropathy. DPN was independently associated with increasing age. Early diagnosis of diabetes mellitus, increased diabetes knowledge and regular blood sugar screenings would play an important role in identifying this problem.

Keywords: Diabetic peripheral neuropathy, associated factors, newly diagnosed, diabetes mellitus.

DOI: https://dx.doi.org/10.4314/ahs.v17i2.21

Cite as: Kisozi T, Mutebi E, Kisekeka M, Lhatoo S, Sajatovic M, Kaddumukasa M, Nakwagala FN, Katabira E. Prevalence, severity and factors associated with peripheral neuropatby among newly diagnosed diabetic patients attending Mulago hospital: a cross-sectional study. Afri Health Sci. 2017;17(2): 463-473. bttps:// dx.doi.org/10.4314/abs.v17i2.21
\end{abstract}

\section{Introduction}

The International Diabetes Federation (IDF) estimates that 19.8 million people have diabetes in Africa where approximately $75 \%$ are still undiagnosed ${ }^{1}$. With the incidence of diabetes on the rise, the incidence of diabetic complications like peripheral neuropathy is also expected to increase correspondingly ${ }^{2}$. Approximately 50 percent of patients with diabetes are estimated to develop neu-

\section{Corresponding author:}

Mark Kaddumukasa, Department of Medicine, School of Medicine, Makerere University, College of Health Sciences, P.O. Box 7072 Kampala, Uganda.

Email: kaddumark@yahoo.co.uk ropathy depending on disease duration and diabetic con$\mathrm{trol}^{3}$. Diabetic peripheral neuropathy is the commonest complication of diabetes mellitus, and a major cause of limb amputations ${ }^{4}$.

The primary symptom of diabetic peripheral neuropathy (DPN) is abnormal or loss of sensation in the toes, which extends to involve the feet and leg in a stocking distribution $^{5,6}$. DPN predisposes to substantial morbidity, which includes not only susceptibility to foot or ankle fractures and ulceration leading to lower-limb amputations, but also neuropsychiatric co-morbidity such as depression ${ }^{7,8}$. These situations can negatively impact the quality of life of affected individuals. In general, however, the magnitude of diabetic neuropathy in sub-Saharan Africans with diabetes has been less reliably quantified. There is paucity of data on prevalence of peripheral neuropathy and factors associated with peripheral neuropathy among newly 
diagnosed diabetic patients in Uganda. In this study, we determined the prevalence and factors associated with peripheral neuropathy among newly diagnosed diabetic patients attending Mulago teaching hospital.

\section{Methods}

\section{Setting and study design}

This was a cross sectional study carried out in the Mulago National Referral Teaching Hospital diabetic clinics and wards. The diagnosis of diabetes was based on i). a glycated hemoglobin A1C level $\geq 6.5 \%$, ii). A fasting plasma glucose $(\mathrm{FPG}) \geq 126 \mathrm{mg} / \mathrm{dL}(7.0 \mathrm{mmol} / \mathrm{L})$. Fasting was defined as no caloric intake for at least $8 \mathrm{~h}$ and iii). a prior clinical diagnosis (e.g., a patient in a hyperglycemic crisis or with classic symptoms of hyperglycemia and a random plasma glucose $\geq 200 \mathrm{mg} / \mathrm{dL})^{9}$. We classified smokers as having a history of smoking and no history of smoking, while alcohol was categorized as current alcohol consumption and no alcohol consumption.

\section{Sample size estimation}

Sample size for prevalence was based on a study done by Dr. Pario Aldo in 2011(Masters' thesis unpublished data) which gave the highest sample size. Required sample size is estimated using Keish and Leslie formula (1965) for estimating prevalence is 288 using the prevalence of $75 \%$ $\mathrm{N}=$ Z2 P (1-P) / 82 . Where, $\mathrm{N}=$ the sample size, $\mathrm{Z}=$ the standard normal deviate at $95 \%$ confidence (1.96), $\mathrm{P}=$ Estimated prevalence is $0.75, \delta 2=$ precision $(0.05)$. Therefore 288 newly diagnosed diabetics were enrolled into this study.

\section{Subject enrollment}

Eligible subjects, who provided written informed consent and met the inclusion criteria, were consecutively enrolled into this study from $1^{\text {st }}$ December 2014 to $31^{\text {st }}$ March 2015.

The inclusion criteria of study included; subjects aged 18 years and above, newly diagnosed with diabetes with no prior history or medication of diabetes mellitus. We excluded subjects with chronic lower back pain, neurological history and clinical exam suggestive of myelopathies or radiculopathies, subjects with a Glasgow Coma Scale of $<15$ or who were aphasic and unable to cooperate with neurological examination.

\section{Ethical considerations}

Study approval was obtained from School of Medicine Research and Ethics committee (SOMREC), Makerere University College of Health Sciences Ref Number 2014 -148 and Uganda National Council of Science and Technology. Written informed consent was sought from all study participants and patient confidentiality was ensured.

\section{Study procedures}

A pretested study questionnaire was administered to collect demographic information as well as medical history of diabetes and related diseases. Study subjects were consecutively enrolled until the desired sample size was attained. A complete physical examination was performed including height in meters, weight in kilograms and blood pressure in $\mathrm{mmHg}$. Blood pressure was taken with manual Sphygmomanometer with appropriate cuff sizes for the patient arms. High blood pressure was defined as systolic blood pressure $\geq 140 \mathrm{mmHg}$ or diastolic pressure $\geq$ $90 \mathrm{mmHg}^{10}$. Body Mass Index was calculated as weight divided by height squared $\left(\mathrm{kg} / \mathrm{m}^{2}\right)$.

\section{Peripheral neuropathy screening and assessment}

Neuropathy Disability Score (NDS): NDS consisted of four clinical tests on both feet. The procedure was explained and the tests applied on the patient's hand prior to the examination. The patient closed the eyes during the examination. Each test was assessed with points to calculate the total disability score. The clinical tests were carried as follows: Pressure sensation was assessed using $10 \mathrm{~g}$ (5.07) monofilament at 4 of the 10 standard sites of the sole of the feet (plantar base of the big toe, 2nd and 5th toes and at the heel), avoiding areas with callosity. Vibration sense was elicited using a $128 \mathrm{~Hz}$ turning fork at the hallux of the big toe. Pain perception was assessed by application of pin prick on the proximal part of the great toe to barely depress skin and results classified as present when patient could distinguish sharpness or absent when the patient was unable to distinguish it. The 3 perceptions were scored 0 if present and normal, and 1 if absent, reduced, or uncertain. Achilles deep tendon reflex was tested using standard patellar hammer and technique and graded as either 0 if present (normal), 1 if present with reinforcement or 2 if absent ${ }^{11}$. Where there was previous foot amputation, the score awarded to the examined foot was doubled. The NDS system is made 
of neuropathy score range from 0 - 10 which could also be used to assess severity of peripheral neuropathy. The severity of neuropathy disability was graded as follows: mild (scores: 3-5), moderate (scores: 6-8), and severe (scores: 9-10) ${ }^{12}$. The NDS was validated and found to be 65\% sensitive and 91\% specific for diagnosing diabetic neuropathy ${ }^{13}$.

Neuropathy Symptom Score (NSS): All patients were asked whether they experienced pain or discomfort in their legs. A description of burning, numbness, or tingling was assigned a score of 2 , and fatigue, cramping, or aching was assigned a score of 1 . If the patient described the symptoms as occurring in their feet, calves, and elsewhere, scores of 2, 1 , and 0 were assigned, respectively. Nocturnal exacerbation of symptoms was scored as exacerbation of symptoms during the day as well as night was scored as 1 , and exacerbation of symptoms during the daytime alone was scored as 0 . If the symptoms had ever woken the patient from sleep, a score of 1 was assigned. The patients were asked if any maneuver could reduce their symptoms; walking was assigned a score of 2 , standing 1 , and sitting or lying down 0 . Thus, the maximum symptom score was 9 , and the severity of symptoms was graded as follows: mild (scores: 3-4), moderate (scores: 5-6), and severe (scores: 7-9) ${ }^{14,15}$. Gentile et al. found the symptoms to be $87 \%$ sensitive and $60 \%$ specific when compared to the gold standard nerve conduction studies (NCS) as reference ${ }^{16}$.

The diagnosis of DPN depends on both subjective symptoms and signs of neuropathy. We defined DPN as at least moderate signs (NDS $\geq 6$ ) according to Neuropathy Disability score with or without symptoms, or mild signs (NDS $\geq 3$ ) with moderate symptoms ( NSS $\geq 5$ ) using Neuropathy symptom score ${ }^{17,18}$.

Laboratory investigations: were performed on all study participants. These included a random serum lipid profile, glycated hemoglobin levels and vitamin B 12 complex levels.

Blood collection: under aseptic techniques, a vein preferably in the antecubital fossa which was identified and between $6 \mathrm{mls}$ of whole blood was drawn. It was then dispensed in to yellow top vacutainers for lipid profile
(HDL, LDL, Total Cholesterol), red vacutainers for Vitamin B 12 levels and purple top vacutainers for HBA1C. The blood in each tube was mixed gently and immediately delivered to the Mulago chemistry laboratory for analysis. For the serum lipid profile and vitamin B12 levels, the Cobas intergra machine was utilized. For HBA1C, high-performance liquid chromatography (HPLC) was used.

\section{Statistical analysis}

Statistical analysis was performed using STATA software version 12 (Stata Corporation, College Station, TX, USA). Continuous data have been expressed as mean $\pm \mathrm{SD}$ and categorical data as numbers and percentages. Variables associated with DPN were tested using bi-variable analysis. All factors with $\mathrm{p}<0.2$ at bi-variable analysis were included in multivariable analysis using a multiple logistic regression. Collinearity analysis found a significant association between age and history of hypertension $(\mathrm{p}<0.001)$. Two models one including age and the other including history of hypertension were then fitted and compared using AIC. A model with age (excluding history of hypertension) had the smallest AIC (260.36 compared to 266.0) and was considered a better fit. Goodness of fit test of this model was also done and was found to be fairly a good fit $(p=0.065)$. The results of this model are shown under the adjusted results column. A P value $<0.05$ was considered significant.

\section{Results}

\section{Baseline socio-demographic factors}

A total of two hundred forty-eight newly diagnosed diabetic patients were enrolled into this study. The mean age $( \pm S D)$ of study participants was 48.5 (13.4) years. Of all the two hundred forty eight study participants, one hundred and fifty four were male, (62\%) and 194 (78.2 $\%$ ) were above 40 years. Fifty-six percent (140/248) were married while $76.2 \%(189 / 248)$ were residents from urban areas. Fifty-four percent $(134 / 248)$ had only primary level education. Fifty-seven percent $(140 / 248)$ of them were earning income below 200,000 shillings as shown in Table 1. 
Table 1: Social demographic characteristics of newly diagnosed diabetic patients attending Mulago Hospital

\begin{tabular}{|c|c|c|}
\hline & $\begin{array}{c}\text { Frequency } \\
\mathbf{N}=\mathbf{2 4 8}\end{array}$ & $\begin{array}{c}\text { Percentage } \\
(\%)\end{array}$ \\
\hline \multicolumn{3}{|c|}{ Age categories in years } \\
\hline$<40$ & 54 & 21.8 \\
\hline $40-49$ & 75 & 30.2 \\
\hline $50-59$ & 64 & 25.8 \\
\hline$\geq 60$ & 55 & 22.2 \\
\hline \multicolumn{3}{|l|}{ Gender } \\
\hline Female & 94 & 37.9 \\
\hline Male & 154 & 62.1 \\
\hline \multicolumn{3}{|l|}{ Marital status } \\
\hline Single & 27 & 10.9 \\
\hline Married & 140 & 56.5 \\
\hline Separated & 49 & 19.8 \\
\hline Widowed & 32 & 12.9 \\
\hline \multicolumn{3}{|l|}{ Residence } \\
\hline Urban & 189 & 76.2 \\
\hline Rural & 59 & 23.8 \\
\hline \multicolumn{3}{|c|}{ Level of education } \\
\hline None & 34 & 13.7 \\
\hline Primary & 134 & 54.0 \\
\hline Secondary & 61 & 24.6 \\
\hline Post-secondary & 19 & 7.7 \\
\hline \multicolumn{3}{|c|}{ Income level in Uganda shillings (Ugx) } \\
\hline$<200,000$ & 140 & 56.5 \\
\hline$\geq 200,000$ & 108 & 43.5 \\
\hline
\end{tabular}

Prevalence and severity of peripheral neuropathy among newly diagnosed diabetic patients.

The prevalence of peripheral neuropathy was $29.4 \%$ (73/248) using the NDS and NSS criteria. The mean age $( \pm S D)$ in years among those with peripheral neuropathy and those without peripheral neuropathy was 54.1 (12.6) and 46.8 (13.2) respectively. The mean age in years was different among these two groups with p-value of $<0.001$, (OR; 95\% CI: $1.04(1.02-1.07)$. There were no significant differences in these two groups in the BMI $\mathrm{kg} / \mathrm{m} 2.70 .6 \%(175 / 248)$ had no peripheral neuropathy.
Among study subjects with peripheral neuropathy, 53.4\% (39/73) had moderate neuropathy with NDS score of 6-8, 30.2\% (22/73) had mild while 16.4\% (12/73) had severe peripheral neuropathy with NDS scores of 9-10. Half of the newly diagnosed diabetic patients with severe clinical neuropathy (NDS >8) had painful neuropathic symptoms (i.e. NSS $\geq 5$ ), while only $14.2 \%$ of patients without clinical neuropathy (NDS $\leq 2$ ) had painful symptoms using the neuropathy disability score. Thirty-three percent of newly diagnosed diabetics with severe neuropathy had no clinical symptom (NSS 0-2) (See figure 1). 


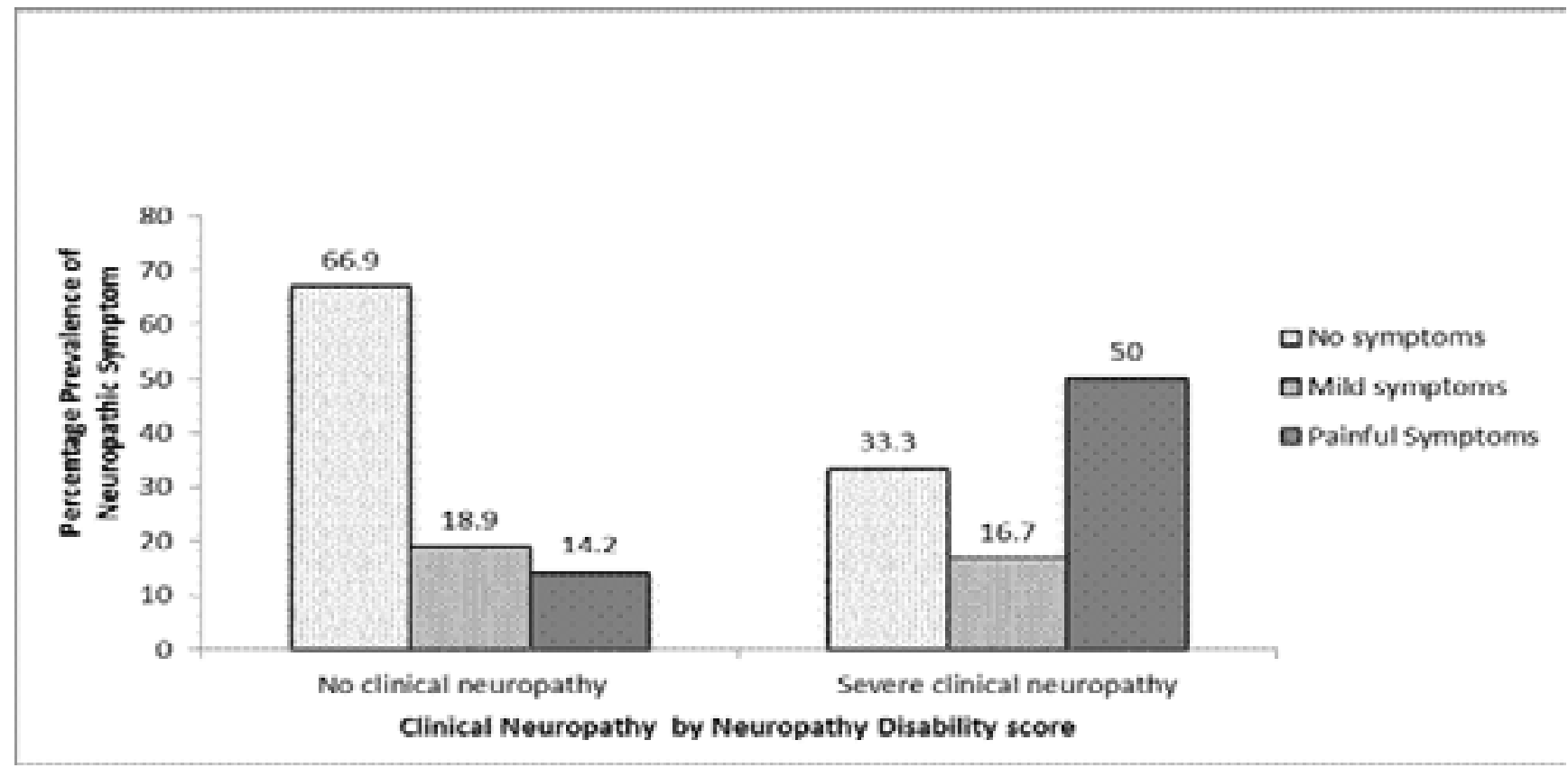

Figure 1: Relationship between neuropathy symptoms and clinical severity of neuropathy

Factors associated with peripheral neuropathy in al neuropathy, (OR 6.05, 95\% CI, $2.08-17.63, \mathrm{p}=0.001)$. newly diagnosed patients

The age 60 years and above was associated with peripherGender, level of education and income level were not associated with peripheral neuropathy with p-values of $0.254,0.519$ and 0.127 respectively (Table 2 ).

Table 2: Associations between socio-demographic factors and peripheral neuropathy.

\begin{tabular}{|c|c|c|c|c|}
\hline $\begin{array}{l}\text { Categorical socio- } \\
\text { demographic factors }\end{array}$ & $\begin{array}{l}\text { Neuropathic } \\
\text { N (\%) }\end{array}$ & $\begin{array}{c}\text { None- } \\
\text { neuropathic } \\
\text { N (\%) } \\
\end{array}$ & OR $(95 \%$ CI $)$ & p value \\
\hline \multicolumn{5}{|l|}{ Age categories in years } \\
\hline$<40$ & $5(8.3)$ & $49(26.1)$ & Reference & \\
\hline $40-49$ & $14(23.3)$ & $61(32.5)$ & $2.25(0.76-6.68)$ & 0.144 \\
\hline $50-59$ & $20(33.3)$ & $44(23.4)$ & $4.45(1.54-12.87)$ & $0.006 *$ \\
\hline$\geq 60$ & $21(35.0)$ & $34(18.1)$ & $6.05(2.08-17.63)$ & 0.001* \\
\hline \multicolumn{5}{|l|}{ Gender } \\
\hline Male & $19(31.7)$ & 75 (39.9) & Reference & \\
\hline Female & $41(68.3)$ & $113(60.1)$ & $1.43(0.77-2.66)$ & 0.254 \\
\hline \multicolumn{5}{|l|}{ Marital status } \\
\hline Married & $33(55.0)$ & $107(56.9)$ & Reference & \\
\hline Single & $3(5.0)$ & $24(12.8)$ & $0.41(0.11-1.43)$ & 0.161 \\
\hline No & $29(48.3)$ & $129(68.6)$ & Reference & \\
\hline Yes & $31(51.7)$ & $59(31.4)$ & $2.34(1.29-4.23)$ & $0.005^{*}$ \\
\hline \multicolumn{5}{|l|}{$\begin{array}{l}\text { Current alcohol } \\
\text { consumption }\end{array}$} \\
\hline No & $51(85.0)$ & $146(77.7)$ & Reference & \\
\hline Yes & $9(15.0)$ & $42(22.3)$ & $0.61(0.28-1.35)$ & 0.224 \\
\hline
\end{tabular}


Socio-demographic and clinical factors: Among study subjects the delay in initiating treatment of more than 1 year was associated with peripheral neuropathy, (OR 1.89; $95 \%$ CI: $1.03-3.48), \mathrm{p}=0.041)$. The history of ever hav- ing a foot ulcer and hypertension were significantly associated with peripheral neuropathy with (OR 2.59; 95\% CI: $1.03-6.49, \mathrm{p}=0.042)$ and (OR 2.34, 95\% CI 1.29 $-4.23, \mathrm{p}=0.005)$ respectively (Table 3).

Table 3:Associations between clinical history factors and peripheral neuropathy.

\begin{tabular}{|c|c|c|c|c|}
\hline Clinical factors & $\begin{array}{l}\text { Neuropathic } \\
\mathrm{N}(\%)\end{array}$ & $\begin{array}{l}\text { None-neuropathic } \\
\mathrm{N}(\%)\end{array}$ & OR $(95 \% \mathrm{Cl})$ & P-value \\
\hline $\begin{array}{l}\text { Duration before diagnosed } \\
\text { with diabetes }^{1} \\
<1 \text { year (no delay) } \\
\geq 1 \text { year (delay) }\end{array}$ & $\begin{array}{l}36(60.0) \\
24(40.0)\end{array}$ & $\begin{array}{l}139(73.9) \\
49(26.1)\end{array}$ & $\begin{array}{l}\text { Reference } \\
1.89(1.03-3.48)\end{array}$ & $0.041^{*}$ \\
\hline $\begin{array}{l}\text { History of family DM } \\
\text { No } \\
\text { Yes }\end{array}$ & $\begin{array}{l}32(53.3) \\
28(46.7)\end{array}$ & $\begin{array}{l}110(58.5) \\
78(41.5)\end{array}$ & $\begin{array}{l}\text { Reference } \\
1.23(0.69-2.21)\end{array}$ & 0.481 \\
\hline $\begin{array}{l}\text { Ever had foot ulcer } \\
\text { No } \\
\text { Yes }\end{array}$ & $\begin{array}{r}51(85.0) \\
9(15.0)\end{array}$ & $\begin{array}{c}176(93.6) \\
12(6.4)\end{array}$ & $\begin{array}{l}\text { Reference } \\
2.59(1.03-6.49)\end{array}$ & $0.042^{*}$ \\
\hline $\begin{array}{l}\text { History of smoking } \\
\text { No } \\
\text { Yes }\end{array}$ & $\begin{array}{l}52(86.7) \\
8(13.3)\end{array}$ & $\begin{array}{l}167(88.8) \\
21(11.2)\end{array}$ & $\begin{array}{l}\text { Reference } \\
1.22(0.51-2.93)\end{array}$ & 0.650 \\
\hline $\begin{array}{l}\text { History of hypertension } \\
\text { No } \\
\text { Yes }\end{array}$ & $\begin{array}{l}29(48.3) \\
31(51.7)\end{array}$ & $\begin{array}{l}129(68.6) \\
59(31.4)\end{array}$ & $\begin{array}{l}\text { Reference } \\
2.34(1.29-4.23)\end{array}$ & $0.005^{*}$ \\
\hline $\begin{array}{l}\text { Current alcohol } \\
\text { consumption } \\
\text { No } \\
\text { Yes }\end{array}$ & $\begin{array}{l}51(85.0) \\
9(15.0)\end{array}$ & $\begin{array}{l}146(77.7) \\
42(22.3)\end{array}$ & $\begin{array}{l}\text { Reference } \\
0.61(0.28-1.35)\end{array}$ & 0.224 \\
\hline
\end{tabular}

${ }^{1}$ Duration before diagnosing study patients with diabetes from the estimated start of diabetic symptoms like polyuria and polydipsia *statistically significant

Table 4 shows bivariate analysis of laboratory results and diabetic peripheral neuropathy where $76.7 \%(\mathrm{P}=0.737)$ of patients with neuropathy had abnormal HBA1C. Vi- tamin $\mathrm{B}_{12}$ was abnormal in only $1.7 \%(\mathrm{P}=0.579)$ of patients with peripheral neuropathy. Normal lipid profile was generally protective against peripheral neuropathy. All the results were not statistically significant. 
Table 4: Associations between laboratory results and peripheral neuropathy.

\begin{tabular}{|c|c|c|c|c|}
\hline Laboratory results & Neuropathic N(\%) & $\begin{array}{l}\text { None-neuropathic } \\
\mathrm{N}(\%)\end{array}$ & OR $(95 \% \mathrm{Cl})$ & P-value \\
\hline $\begin{array}{l}\text { HbA1C \% } \\
\text { Normal (2.9 -7) } \\
\text { Abnormal > } 7\end{array}$ & $\begin{array}{l}14(23.3) \\
46(76.7)\end{array}$ & $\begin{array}{l}40(21.3) \\
148(78.7)\end{array}$ & $\begin{array}{l}1.13(0.56-2.25) \\
\text { Reference }\end{array}$ & 0.737 \\
\hline $\begin{array}{l}\text { Vitamin B12 ph/ml } \\
\text { Normal }(191-946) \\
\text { Abnormal }\end{array}$ & $\begin{array}{c}58(98.3) \\
1(1.7)\end{array}$ & $\begin{array}{c}186(98.9) \\
2(1.1)\end{array}$ & $\begin{array}{l}0.79(0.34-1.82) \\
\text { Reference }\end{array}$ & 0.579 \\
\hline $\begin{array}{l}\text { Cholesterol } \mathrm{mmol} / \mathrm{L} \\
\text { Normal }(<5.7) \\
\text { Abnormal }>5.7\end{array}$ & $\begin{array}{l}42(70.0) \\
18(30.0)\end{array}$ & $\begin{array}{r}143(76.1) \\
45(23.9)\end{array}$ & $\begin{array}{l}0.73(0.38-1.40) \\
\text { Reference }\end{array}$ & 0.349 \\
\hline $\begin{array}{l}\text { HDL mmol/L } \\
\text { Normal (>0.9) } \\
\text { Abnormal }\end{array}$ & $\begin{array}{l}38(63.3) \\
22(36.7)\end{array}$ & $\begin{array}{r}127(67.6) \\
61(32.4)\end{array}$ & $\begin{array}{l}0.83(0.45-1.52) \\
\text { Reference }\end{array}$ & 0.547 \\
\hline $\begin{array}{l}\text { LDL mmol/L } \\
\text { Normal (<3.37) } \\
\text { Abnormal }\end{array}$ & $\begin{array}{l}37(61.7) \\
23(38.3)\end{array}$ & $\begin{array}{l}118(62.8) \\
70(37.2)\end{array}$ & $\begin{array}{l}0.95(0.52-1.74) \\
\text { Reference }\end{array}$ & 0.878 \\
\hline
\end{tabular}

Subsequent multivariate analysis showed that age groups, $50-59$ years (OR 3.72; 95\% CI $1.25-11.03$ ) $\mathrm{p}=0.018$ ) and those aged $\geq 60$ years (OR 6.62, 95\% CI $2.22-19.70$, $\mathrm{p}=0.001)$ were independently associated with peripheral neuropathy. The history of ever having a foot ulcer was associated with peripheral neuropathy (OR 2.98; 95\% CI: $1.11-8.02, \mathrm{p}=0.031)$ (Table 5). 
Table 5: Unadjusted and adjusted effects for factors associated with peripheral neuropathy using a logistic regression.

\begin{tabular}{|c|c|c|c|c|}
\hline & $\begin{array}{l}\text { Unadjusted OR } \\
(95 \% \mathrm{CI})\end{array}$ & P value & $\begin{array}{l}\text { Adjusted OR } \\
(95 \% \mathrm{CI})\end{array}$ & P value \\
\hline \multicolumn{5}{|l|}{ Age } \\
\hline$<40$ & Reference & & Reference & \\
\hline $40-49$ & $2.25(0.76-6.68)$ & 0.144 & $2.07(0.68-6.28)$ & 0.197 \\
\hline $50-59$ & $4.45(1.54-12.87)$ & 0.006 & $\begin{array}{l}3.72(1.25- \\
11.03)\end{array}$ & 0.018 \\
\hline$\geq 60$ & $6.05(2.08-17.63)$ & 0.001 & $\begin{array}{l}6.62(2.22- \\
19.70)\end{array}$ & \\
\hline \multicolumn{5}{|c|}{$\begin{array}{l}\text { Duration before diagnosed } \\
\text { with diabetes }\end{array}$} \\
\hline$<1$ year (no delay) & Reference & & Reference & \\
\hline$\geq 1$ year (delay) & $1.89(1.03-3.48)$ & 0.041 & $1.79(0.94-3.44)$ & 0.077 \\
\hline \multicolumn{5}{|l|}{ Missed diagnosis } \\
\hline No & Reference & & Reference & \\
\hline Yes & $2.59(1.03-6.49)$ & 0.042 & $2.85(1.05-7.75)$ & 0.040 \\
\hline \multicolumn{5}{|l|}{ Ever had foot ulcer } \\
\hline No & Reference & & Reference & \\
\hline Yes & $2.59(1.03-6.49)$ & 0.042 & $2.98(1.11-8.02)$ & 0.031 \\
\hline
\end{tabular}

\section{Discussion}

Peripheral neuropathy remains a challenge among diabetic patients and early institution of hypoglycemic agents may slow its progression. Increasing age, longer duration of diabetes and poor glycemic control are well recognized risk factors for peripheral neuropathy while cigarette smoking, retinopathy, hypertension, obesity, hyperlipidemia and micro-albuminuria have also been implicated as potential risk markers ${ }^{19}$.

\section{Prevalence of diabetic peripheral neuropathy}

The overall prevalence of DPN among newly diagnosed diabetic patients was $29.4 \%$. This is the first study to assess the severity and factors associated with peripheral neuropathy in Uganda among newly diagnosed diabetics, earlier studies have described peripheral neuropathy among patients' attending the out-patient clinics and receiving hypoglycemic agents. This prevalence is lower than a prevalence of $46.4 \%$ reported from a chart review of newly diagnosed diabetics reported in Uganda ${ }^{20}$. However, this study among newly diagnosed diabetics was based on symptoms and no assessment of severity was performed. It is also important to note that a third of the study participants with clinically severe neuropathic signs had no clinical symptoms This study had similar findings to other studies in India, Egypt, with a prevalence of $29 \%$ using the same diagnostic criteria ${ }^{21,22}$. In various Western populations, the prevalence of DPN in newly diagnosed diabetic patients varies widely from $10 \%$ to $48 \% \%^{23-25}$. In other studies, from sub -Saharan Africa, Osuntokun in Nigeria reported higher levels of $48 \%$ while the frequency of peripheral neuropathy has been reported to vary from $9.5-36.4 \%$ among diabetic patients. These conflicting figures may be due to the differences in the methodologies and techniques of diagnosing peripheral neuropathy ${ }^{26,27}$.

This may be due to different methodologies employed for detection of neuropathy such as the use of nerve conduction studies as well as variability in patient ages and time elapsed before diagnosis. However, racial differences in DPN may also be relevant within these populations ${ }^{28}$. This high prevalence of DPN among newly diagnosed diabetics indicates that our patients may be presenting late to clinics for attendant care. This may be attributed to low knowledge, attitudes or mis-diagnosis/delayed diagnosis in Uganda. Lack of regular medical care and poor health seeking behavior may play an important role.

\section{Severity of diabetic peripheral neuropathy}

Most of the patients had moderate to severe neuropathy with high neuropathic symptom scores. Approximately half of our patients with clinically severe neuropathy had no or mild symptoms which was consistent with a study in United Kingdom in $48 \%$ of patients ${ }^{29}$. Further- 
more, approximately $15 \%$ of our patients without clinical neuropathy on examination had significant painful neuropathic symptoms (NSS $\geq 5$ ), indicating the large disparity between signs and symptoms. Diabetic patients with impaired glucose tolerance and no apparent neuropathy develop painful neuropathic symptoms and small nerve fiber damage $e^{30}$. This poses a challenge in assessing for this condition if $50 \%$ of the patients have no symptoms and hence requires a good clinical examination on all diabetic patients irrespective of symptoms of neuropathy. This emphasizes the need not only to inquire about these symptoms but also to perform a neurological examination to make an early diagnosis.

\section{Factors associated with Diabetic peripheral neurop- athy}

Previous studies have identified several risk factors for DPN such as age, poor glycemic control, the duration of diabetes, gender, height, body mass index, retinopathy, hypertension, smoking, alcohol consumption and foot ulcers $^{23,24,31}$. In the current study, age at diagnosis and history of foot ulcers were independent risk factors for DPN. For each decade increase in age, the prevalence of DPN increased significantly and the mean age (SD) for DPN was 54.1 (12.6). This mean age is similar to that in other studies from Nigeria $(54.8 \pm 12.1)^{32}$, Bangladesh (54.8 \pm 12.1 $)^{33}$, India $(51.3 \pm 12.3)^{34}$ and $\operatorname{Iran}(57.0 \pm 10.6)^{35}$. However it was higher in China $(69.6 \pm 9.5)^{36}$ and Sir Lanka $(62.1 \pm 10.8)^{37}$ because their study population was above 50 years which was relatively older than ours.

\section{Limitations}

The study had various limitations, the diagnosis of peripheral neuropathy is improved by nerve conduction testing unfortunately this test is not available here which could have led to under diagnosis. This was a referral hospital setting so the results may not be generalized to the whole of Uganda. Triglycerides were not considered since patient did not fast which could underestimate the role of lipids as associated factors for peripheral neuropathy. This was because it was inconvenient to keep the patient fasting for 8 hours before fasting blood samples were taken.

\section{Conclusion}

$29.4 \%$ of recently diagnosed patients with diabetes had DPN. DPN was associated with an age of 60 years and above as well as history of foot ulcers. There is an urgent need to routinely screen for diabetes among the elderly population and examine newly diagnosed diabetic patients irrespective of their clinical symptoms. Screening for DPN may be a cost-effective means to prevent diabetic foot ulcers in Ugandan patients.

\section{Conflicts of interest}

None

\section{Authors' contributions}

TK, FNN, EM, MK, MK, SL and MS designed the study, TK collected the data during the study, EM and TK performed data analysis with Levi Mugenyi. TK, FNN, EM, MK, MK, SL and MS wrote the paper. All authors discussed the results and approved the manuscript for submission.

\section{Acknowledgements}

This study was supported by the National Institute of Neurological Disorders and Stroke of the National Institute of Health under MEPI - Neurology linked award number R25NS080968 and the Belgium Technical Cooperation(BTC). We thank Levi Mugenyi, Doreen Birungi and Nebehu Shone for the support and guidance. We also thank our survey subjects for participating in this study.

\section{References}

1. International Diabetes Federation. IDF diabetes atlas 2013 22nd May 2016 Available from: https://www.idf. org/sites/default/files/EN_6E_Atlas_Full_0.pdf.

2. Wild S, Roglic G, Green A, Sicree R, King H. Global prevalence of diabetes: estimates for the year 2000 and projections for 2030. Diabetes Care. 2004 May;27(5):104753'."http://dx.doi.org/10.2337/diacare.27.5.1047".

3. Dyck PJ, Kratz KM, Karnes JL, Litchy WJ, Klein R, Pach JM. The prevalence by staged severity of various types of diabetic neuropathy, retinopathy, and nephropathy in a population-based cohort: The Rochester Diabetic Neuropathy Study. Neurology. April 1993; 43(4):817-24PubMedhttp://dx.doi.org/10.1212/WNL.43.4.817

4. Bild DE, Selby JV, Sinnock P, Browner WS, Braveman $\mathrm{P}$, Showstack JA. Lower-extremity amputation in people with diabetes. Epidemiology and prevention. Diabetes Care. 1989 Jan;12(1):24-31,

5. Morkrid K, Ali L, Hussain A. Risk factors and prevalence of diabetic peripheral neuropathy: A study of type 2 diabetic out-patients in Bangladesh. Int J Diabetes Dev 
Ctries. 2010 Jan;30(1):11-7'."10.4103/0973-3930.60004".

6. Tracy JA, Dyck PJ. The spectrum of diabetic neuropathies. Phys Med Rebabil Clin N Am. 2008 Feb;19(1):1-26, v'."10.1016/j.pmr.2007.10.010\& quot;. PubMed

7. Vincent, Andrea M, Callaghan, Brian C, Smith, Andrea L, et al. Diabetic neuropathy: cellular mechanisms as therapeutic targets. Nat Rev Neurol. 2011;7(10):573-83 PubMed, doi:10.1038/nrneurol.2011.137

8. Coffey JT, Brandle M, Zhou H, Marriott D, Burke R, Tabaei BP, et al. Valuing health-related quality of life in diabetes. Diabetes care. 2002;25:2238-43 PubMed, http:// dx.doi.org/10.2337/diacare.25.12.2238

9. American Diabetes Association. Classification and diagnosis of diabetes. Sec. 2. In Standards of Medical Care in Diabetes 2015. Diabetes Care. 2015;38(Suppl. 1):S8 S16,

10. WHO. Guidelines Subcommittee (1999) World Health Organization-International Society of Hypertension. Guidelines for the Management of Hypertension. J Hypertens. 1999;17:151-83 PubMed

11. Cabezas-Cerrato. The prevalence of clinical diabetic polyneuropathy in Spain: a study in primary care and hospital clinic groups. Neuropathy Spanish Study Group of the Spanish Diabetes Society (SDS). Diabetologia. 1998; 41: 1263- 9, doi; 10.1007/s001250051063. PubMed

12. Young MJ, Breddy JL, Veves A, Boulton AJ. The prediction of diabetic neuropathic foot ulceration using vibration perception thresholds. A prospective study. Diabetes Care. 1994 Jun;17(6):557-60,

13. Dyck PJ, Bushek W, Spring EM, Karnes JL, Litchy WJ, O'Brien PC, et al. Vibratory and cooling detection thresholds compared with other tests in diagnosing and staging diabetic neuropathy. Diabetes Care. 1987 JulAug;10(4):432-40,

14. Young MJ, Boulton AJ, MacLeod AF, Williams DR, Sonksen PH. Amulticentre study of the prevalence of diabetic peripheral neuropathy in the United Kingdom hospital clinic population. Diabetologia. 1993; 36:150- ;4., doi: 10.1007/BF00400697. PubMed

15. Meijer JW, Smit AJ, Sonderen EV, Groothoff JW, Eisma WH, Links TP. Symptom scoring systems to diagnose distal polyneuropathy in diabetes: the Diabetic Neuropathy Symptom score. Diabet Med. 2002 Nov;19(11):962-5, 16. Gentile S, Turco S, Corigliano G, Marmo R. Simplified diagnostic criteria for diabetic distal polyneuropathy. Preliminary data of a multicentre study in the Cam- pania region. S.I.M.S.D.N. Group. Acta Diabetol. 1995 Mar;32(1):7-12,

17. Daousi C, MacFarlane IA, Woodward A, Nurmikko TJ, Bundred PE, Benbow SJ. Chronic painful peripheral neuropathy in an urban community: a controlled comparison of people with and without diabetes. Diabet Med. 2004 Sep;21(9):976-82'."10.1111/j.1464-5491.2004.01271.x".

18. Daousi C, Benbow SJ, Woodward A, MacFarlane IA. The natural history of chronic painful peripheral neuropathy in a community diabetes population. Diabet Med. 2006 Sep;23(9):1021-4'."10.1111/j.1464-5491.2006.01904.x".

19. Boulton AJM, editor. The importance of abnormal foot pressure and gait in causation of foot ulcers. Chilchester: John Wiley and Sons; 1987.

20. Nambuya AP, Otim MA, Whitehead H, Mulvany D, Kennedy R, Hadden DR. The presentation of newly-diagnosed diabetic patients in Uganda. QJM. 1996 Sep;89(9):705-11, http://dx.doi.org/10.1093/ qjimed/89.9.705

21. Dutta A, Naorem S, Singh T, Wangjam K. Prevalence of peripheral neuropathy in newly diagnosed type 2 diabetics. Int J Diab Dev Countries 2005; 25:30-33.

22. Assaad-Khalil SH, Zaki A, Abdel Rehim A, Megallaa MH, Gaber N, Gamal H, et al. Prevalence of diabetic foot disorders and related risk factors among Egyptian subjects with diabetes. Prim Care Diabetes. 2015 Aug;9(4):297303'."S1751-9918(14)00129-6 [pii]

10.1016/j.pcd.2014.10.010\& quot; PubMed.

23. Spijkerman AM DJ, Nijpels G, Adriaanse MC, Kostense PJ, Ruwaard D, Stehouwer CD, Bouter LM, Heine RJ, . Microvascular complications at time of diagnosis of type 2 diabetes are similar among diabetic patients detected by targeted screening and patients newly diagnosed in general practice: the hoorn screening study.

Diabetes Care. 2003;26(9):2604 - 8 PubMed

24. Ratzmann KP, Raschke M, Gander I, Schimke E. Prevalence of peripheral and autonomic neuropathy in newly diagnosed type II (noninsulin-dependent) diabetes. J Diabet Complications. 1991 Jan-Mar;5(1):1-5,

25. Weerasuriya N, Siribaddana S, Wijeweera I, Dissanayeka A, Wijesekera J, Fernando DJ. The prevalence of peripheral neuropathy in newly diagnosed patients with non-insulin-dependent diabetes mellitus. Ceylon Med J. 1998 Mar;43(1):19-21

26. Drabo PY, Kabore J, Lengani A. [Complications of diabetes mellitus at the Hospital Center of Ouagadougou]. Bull Soc Pathol Exot. 1996;89(3):191-5, 
27. Sobngwi E, Mauvais-Jarvis F, Vexiau P, Mbanya JC, Gautier JF. Diabetes in Africans. Part 1: epidemiology and clinical specificities. Diabetes Metab. 2001 Dec;27(6):62834 ,

28. Abbott C, Garrow A, Carrington A, Morris, Ross EV, Boulton A. North-West diabetes foot care study. Foot ulcer risk is lower in South-Asian and African-Caribbean compared with European diabetic patients in the U.K.: The North-West diabetes foot care study. Diabetes care. 2005;28:1869-75 PubMed . http://dx.doi.org/10.2337/ diacare.28.8.1869

29. Abbott CA, Malik RA, van Ross ER, Kulkarni J, Boulton AJ. Prevalence and characteristics of painful diabetic neuropathy in a large community-based diabetic population in the U.K. Diabetes Care. 2011 Oct;34(10):2220-4. doi: $10.2337 / \mathrm{dc} 11-1108$.

30. Boulton AJ, Malik RA. Neuropathy of impaired glucose tolerance and its measurement. Diabetes care. 2010;33:207;9 PubMed, https://dx.doi.org/10.2337\%2Fdc09-1728

31. Weerasuriya N, Siribaddana S, Dissanayake A, Subasinghe Z, Wariyapola D, Fernando DJ. Long-term complications in newly diagnosed Sri Lankan patients with type 2 diabetes mellitus. QJM. 1998 Jun;91(6):439-43,

32. Solomon, Ugoya, Godwins, Echejoh, Tokunbo A, Ugoya, et al. Clinically Diagnosed Diabetic Neuropathy:Frequency, Types and Severity. J Natl Med Assoc. 2006;98:1763-6 PubMed
33. Mørkrid K, Ali L, Hussain A. Risk factors and prevalence of diabetic peripheral neuropathy: A study of type 2 diabetic outpatients in Bangladesh. Int J Diabetes Dev Ctries. 2010;30(1):11-7,

34. Gill HK, Yadav SB, Ramesh V, Bhatia E. A prospective study of prevalence and association of peripheral neuropathy in Indian patients with newly diagnosed type 2 diabetes mellitus. J Postgrad Med. 2014;60(3):2705'."10.4103/0022-3859.138750".

35. Kiani J, Moghimbeigi A, Azizkhani H, Kosarifard S. The Prevalence and Associated Risk Factors of Peripheral Diabetic Neuropathy in Hamedan, Iran. Arch Iran Med. 2013;16(1):17 - 9,

36. Lu, Bin, Hu, Ji, Wen, Jian, et al. Determination of Peripheral Neuropathy Prevalence and Associated Factors in Chinese Subjects with Diabetes and Pre-Diabetes - ShangHai Diabetic neuRopathy Epidemiology and Molecular Genetics Study (SH-DREAMS). PLoS One. 2013;8(4), PubMed doi:e61053'."10.1371/journal. pone.0061053".

37. Katulanda P, Ranasinghe P, Jayawardena R, Constantine GR, Sheriff MH, Matthews DR. The prevalence, patterns and predictors of diabetic peripheral neuropathy in a developing country. Diabetology \& metabolic syndrome. 2012;4(1):21 PubMed , doi; 10.1186/1758-5996-4-21 